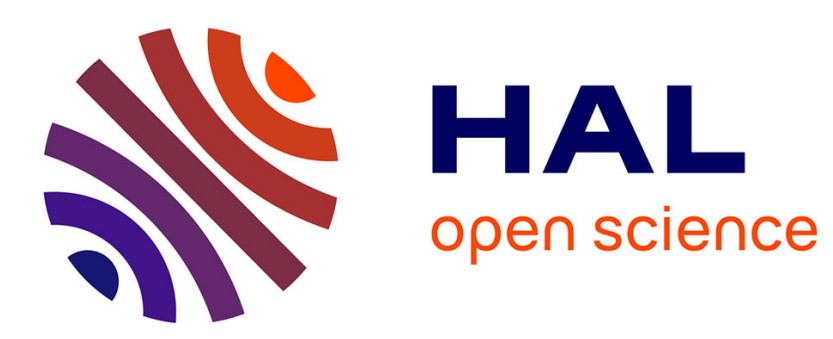

\title{
WHY DO SOME FIRMS CONTRACT OUT PRODUCTION? Evidence from firm-level panel data
}

Carmen Diaz-Mora, Angela Triguero-Cano

\section{To cite this version:}

Carmen Diaz-Mora, Angela Triguero-Cano. WHY DO SOME FIRMS CONTRACT OUT PRODUCTION? Evidence from firm-level panel data. Applied Economics, 2011, pp.1. 10.1080/00036846.2010.548787 . hal-00681222

\section{HAL Id: hal-00681222 \\ https://hal.science/hal-00681222}

Submitted on 21 Mar 2012

HAL is a multi-disciplinary open access archive for the deposit and dissemination of scientific research documents, whether they are published or not. The documents may come from teaching and research institutions in France or abroad, or from public or private research centers.
L'archive ouverte pluridisciplinaire HAL, est destinée au dépôt et à la diffusion de documents scientifiques de niveau recherche, publiés ou non, émanant des établissements d'enseignement et de recherche français ou étrangers, des laboratoires publics ou privés. 


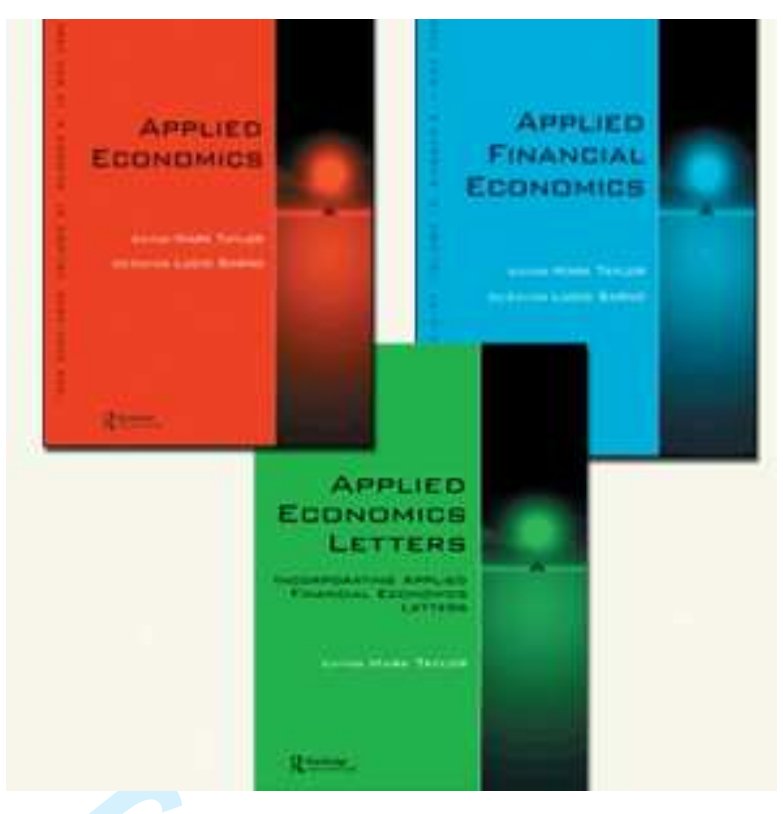

\section{WHY DO SOME FIRMS CONTRACT OUT PRODUCTION? Evidence from firm-level panel data}

\begin{tabular}{|r|l|}
\hline Journal: & Applied Economics \\
\hline Manuscript ID: & APE-2009-0422.R1 \\
\hline Journal Selection: & Applied Economics \\
\hline Dute Submitted by the & 27-Nov-2010 \\
\hline Complete List of Authors: & $\begin{array}{l}\text { Diaz-Mora, Carmen; University of Castilla-La Mancha, Department } \\
\text { of International Economics } \\
\text { Triguero-Cano, Angela; University of Castilla-La Mancha, } \\
\text { Department of International Economics }\end{array}$ \\
\hline JEL Code: & $\begin{array}{l}\text { D21 - Firm Behavior < D2 - Production and Organizations }<\text { D - } \\
\text { Microeconomics, L23 - Organization of Production < L2 - Firm } \\
\text { Objectives, Organization, and Behavior < L - Industrial } \\
\text { Organization, L25 - Firm Size and Performance }<\text { L2 - Firm } \\
\text { Objectives, Organization, and Behavior < L - Industrial } \\
\text { Organization, L60 - General < L6 - Industry Studies: Manufacturing } \\
<\text { L - Industrial Organization }\end{array}$ \\
\hline Keywords: & $\begin{array}{l}\text { Outsourcing, Subcontracting decision, Firm-level panel data, } \\
\text { Determinants, Dynamic probit model }\end{array}$ \\
\hline & \\
\hline
\end{tabular}




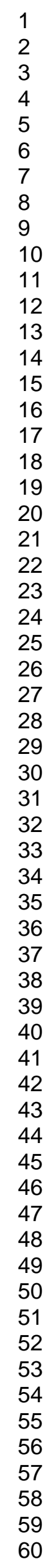

\section{SCHOLARONE ${ }^{m}$ \\ Manuscripts}

7

25

26

27

29

30

32

33

34

35

36

37

39

40

41

42

44

45

46

47

48

49

50

52

53

54

56

57

58

60 


\section{Why do some firms contract out production? Evidence from firm-level panel}

data

C. Díaz-Mora ${ }^{\mathrm{a}}$ and A. Triguero-Cano ${ }^{\mathrm{b}, *}$

${ }^{a}$ Department of International Economics, University of Castilla-La Mancha, 45071 Toledo, Spain

${ }^{b}$ Faculty of Economics and Business, University of Castilla-La Mancha, 02071, Albacete, Spain

* Corresponding author. E-mail: Angela.Triguero@uclm.es

The present article examines which factors determine outsourcing decision using firmlevel data. According to the theoretical and empirical literature, firm, industry and market characteristics influence the likelihood of contracting out. We try to identify which firm characteristics are prerequisites for becoming an outsourcer. Using a dynamic panel data probit model, our results show that firms with previous subcontracting experience, higher wages, frequent market changes, R\&D activities, product differentiation, large size and exporter status are more likely to engage in outsourcing. 


\section{Introduction}

Nowadays there is a broad consensus in academic literature about the meaning of outsourcing which is defined as the act of transferring some of the company's recurring interval activities to outside providers through a contractual arrangement (World Trade Organization, 2005). In this way, firms can focus on their innermost core competences. The term 'outside' refers to external to the boundaries of the company, that is, outsourcing is opposed to vertically integrated production. Moreover, as Grossman and Helpman (2005) note "outsourcing means more than just the purchases of raw materials and standardized intermediate goods" because a specific characteristic of outsourcing is that the relationship between the firm which contracts out production and external provider is a long-term one and it usually implies sharing information about the product. That is why purchases of intermediate inputs through a usual marketing channel have not to be regarded as outsourcing.

Outsourcing is not a new phenomenon. During the last decades, the increasing competition and complexity of production processes have led to firms, particularly those belonging to sectors such as car or electronic industry, to identify and focus on the strategic core competences. But recently, tasks and competences which are considered non-core and are purchased from independent suppliers have dramatically grown. Moreover, outsourcing strategy has extended to other industries and acquired a global dimension.

The main purpose of this article is to study the determinants of outsourcing decisions using firm-level panel data for Spanish manufacturing industries over the period 1991 to 2002. Although academic literature and professional press have discussed the increasing relevance of this strategy in the world economy, empirical 
research at the manufacturing firm-level on factors influencing the choice of outsourcing is still very limited: Kimura (2001) and Holl (2008) for Japanese and Spanish manufacturing firms, respectively ${ }^{1}$. Taking into account that a high proportion of firms are inactive in outsourcing (more than half of firms in our sample), it seems necessary to make more efforts in studying the determinants of the likelihood of outsourcing. The existence of fixed entry costs, which also must be taken into account. According to the theoretical model by Grossman and Helpman (2002), transaction costs can seriously hinder the adoption of outsourcing strategy and their presence would imply persistence in the outsourcing decision. Therefore the impact of previous outsourcing behaviour is an additional regressor in our model of outsourcing decision.

The rest of this article is organized as follows. Section II describes the data and provides the main results from the empirical analysis. Section III examines the determinants of outsourcing following previous theoretical and empirical literature. Section IV develops the econometric model to be estimated while results are presented in Section V. Section VI closes with final remarks.

\section{Data and descriptive analysis}

Our work focuses on outsourcing of production which includes the manufacturing of custom-made finished products or parts and components which have been contracted out to third parties. The processing of the segmented production is carried out following the main contractor's specifications and requirements. This definition corresponds to a particular type of outsourcing, namely, subcontracting,

\footnotetext{
${ }^{1}$ Whereas the first reference is a cross-section analysis, the second is a panel approach although it focuses on the role of agglomeration economies on outsourcing decision. Tomiura (2005), Görg \& Hanley (2004) and Girma \& Görg (2004) study the firm-level determinants of outsourcing intensity instead of outsourcing decision. Another work on outsourcing intensity but using industry-level data is Díaz-Mora (2007).
} 
where the relationship between principal and third-party company is characterized by a "dominant/dominated" nature. Nevertheless, outsourcing could also imply a more strict collaboration between firms involved that is, creating a partnership. Therefore, among outsourcing transactions, different degrees of managerial controllability over outsourced production exist (Kimura and Ando, 2005).

Outsourcing data are obtained from the Encuesta sobre Estrategias Empresariales (ESEE hereafter), a panel survey which offers information about Spanish firms' strategies over the period 1990 to 2002. The survey provides data on many relevant firm characteristics. The ESEE is a representative sample of the population of Spanish manufacturing firms with 10 or more employees. The selection is carried out combining exhaustiveness in the case of firms which have over 200 employees and random sampling criteria for firms which employ between 10 and 200 workers. In the first year, 1990, 2188 firms were interviewed considering the above mentioned criteria (1724 firms in 2002) ${ }^{2}$. In relation to outsourcing, we select exclusively those firms that respond the questions about outsourcing (the overall survey response rate for outsourcing is $97.5 \%$ of total firms $)^{3}$. Fig. 1 reflects the evolution of the outsourcing decision in the period 1991 to 2002. Our results do not show a growing trend in the proportion of firms that decide to outsource production. The percentage of firms engaged in subcontracting is about $45 \%$ all over the period;

\footnotetext{
${ }^{2}$ See www.funep.es for further details about ESEE. We have decided to omit the first year of the ESEE, 1990, due to the lack of some data related to our issue (e.g., the value of production which has been contracted out).

${ }^{3}$ The survey distinguishes two types of outsourcing depending on whether the main contractor provides the materials to the supplier or not. The second type implies a greater independence of the subcontracting firm which has a higher degree of control over the materials.
} 
that is, almost one of every two Spanish manufacturing firms has contracted out parts, components or finished products to independent providers ${ }^{4}$.

If we split the sample by firm size, outsourcing strategy appears more relevant in larger firms (more than 200 workers), where around 55\% of them contracted out production. Nearly $40 \%$ (42.4) of medium firms (from 25 to 200 employees) do outsourcing. Smaller firms (less than 25 employees) are the least active in outsourcing: hardly $35 \%$ of them engaged in subcontracting. Kimura (2001), Holl (2008) and Tomiura (2005) have also found a positive relationship between firm size and subcontracting behaviour. To explain this result, it can be argued that large firms face lower fixed entry cost for outsourcing. The proportion of firms involved in subcontracting by firm size hardly varies a long the period. In any case, the decision to outsource production seems to be clearly influenced by firm size.

At sectoral level, it can be observed that the decision of getting involved in subcontracting arrangements widely varies across industries ${ }^{5}$. Industries such as Machinery and mechanical goods, Electrical equipment and Other transport material are extensively engaged in subcontracting (more than $60 \%$ of firms have contracted out production in the period 1991 to 2002). Manufacturing industries subcontracting over the average are also Textiles and clothing, Editing and printing, Rubber and plastic, Metallic products, Office equipment, Motor vehicles and Other manufacturing (Fig. 2). Outsourcing- intensive industries are the same in Spain than in Japan

\footnotetext{
${ }^{4}$ By type of outsourcing, around $20 \%$ of surveyed firms get involved in subcontracting providing materials, around $20 \%$ in subcontracting without materials and $10 \%$ use both types of subcontracting at the same time.

${ }^{5}$ The evolution of the percentage of firms that subcontract production by sectors can show an erratic behaviour, partially due to changes in the number of firms that answer the survey every year, mainly in those sectors which the number of outsourcers is especially low. The dispersion, measured by the variation coefficient, is more pronounced in branches such as meat products, drinks and wood industry. Nevertheless, industries with larger proportion of firms engaged in subcontracting are the same along the period. Likewise, the Pearson correlation as well as Spearman correlation (which is based on ranking instead of values) between different years is high along the period, therefore we employ the time average in the sectoral analysis of subcontracting.
} 
(Tomiura, 2007). The similarity in industries more active in outsourcing between countries emphasizes the influence of sectoral-specific characteristics in the extent of outsourcing. At last, firms in natural resources intensive industries are the least prone to contract out production ${ }^{6}$.

To sum up, the percentage of firms that subcontract production varies across firm size and across industries. That is, firm-size and industry-specific factors such as the productive process and market-specific characteristics seem to determine the subcontracting decision.

\section{Determinants of subcontracting decision}

A theoretical framework to the study of the determinants of outsourcing is provided by Grossman and Helpman (2002). They examine theoretically the decision between outsourcing or vertical integration of intermediate inputs (make or buy decision) taking into account the trade-off between the costs that arise from search frictions and imperfect contracting (costs derived from outsourcing) and the costs of running a larger and less specialized organization (costs derived from vertical integration $)^{7}$. When costs of producing within the firm exceed those of using external

\footnotetext{
${ }^{6}$ By type of subcontracting, worth mentioning differences are found in Textiles and clothing, Leather and shoes, Chemistry and Other manufacturing where subcontracting decision is highly frequent but it is very biased to subcontracting providing materials. These branches, except Chemistry, are labor intensive with low skill requirements. Here, the competition in prices is very important and competitive advantages are associated to the quality of materials, the design of products, etc. Therefore it is very important to control the materials used and the main contractor prefers to provide them to the subcontracting firm. On the contrary, Metallic products, Machinery and mechanical goods, Office equipment, Motor vehicles and Other transport material clearly show up in subcontracting without materials but do not in subcontracting with materials. These are industries with higher technological content where the most standardized production stages, which are not the core competences of the firm, are contracted out and the need to control the materials diminishes.

${ }^{7}$ To consider the international dimension as well as the ownership dimension, Antras and Helpman (2004) develop a theoretical framework in which, based on productivity and sectoral characteristics,
} 
production, firms will opt for contracting out production. At this point, several aspects need to be considered.

At first of all, the rapid reduction in transportation costs and the revolution in information technology have implied, among other things, a drop in the moving costs and coordination costs in the business over the last decades. Reducing the time and costs associated with finding information and business coordination is lowering transaction costs of outsourcing and favouring it over in-house production. This is one of the reasons why outsourcing is a booming form of industrial organization at present. Furthermore we consider that transaction costs associated with outsourcing are higher at the beginning of implementation of the outsourcing strategy, Moreover, some of them would be sunk entry costs such as the search costs to find a suitable provider. It therefore seems reasonable that the decision about the outsourcing strategy in period $t$ is related to previous outsourcing behaviour. The lagged dependent variable is included in our model to account for this persistence in the outsourcing decision. As far as we know only Swenson (2004) shows that outsourcing exhibits hysteresis caused by sunk entry costs using data of the U.S. offshore assembly $\operatorname{program}^{8}$.

According to theories of outsourcing that include entry sunk costs, the persistence of participation decision in subcontracting from one year to the next is quite high (Table 1). According to our data, $82 \%$ of firms that subcontract production continue subcontracting in the following year. The persistence is even higher for those firms that do not subcontract in a particular year: $86 \%$ of them remain inactive in the following year. The pattern of persistence is also clear at industry-level. In all

firms decide whether to integrate into the production of intermediate inputs or outsource them and firms also choose the location of inputs production (at home or abroad).

${ }^{8}$ Other empirical research about outsourcing intensity also consider the influence of previous outsourcing (Girma and Görg, 2004; Díaz-Mora, 2007). 
industries, firms that do subcontracting in the present year tend to outsource production again the next year. Our estimates indicate a probability range of $64 \%$ in Drinks to $88 \%$ in Electrical equipment. The probabilities of remaining inactive in subcontracting in the following year are usually higher, varies between $76 \%$ in Editing and printing and $92 \%$ in Other goods and tobacco.

Advocates of outsourcing have traditionally warned that outsourcing should not be seen as a simply cost-cutting strategy. Nevertheless, labour cost reduction continues to be a major motivation for many employers. Since we assume that labour cost can be reduced by outsourcing (when external suppliers have lower wages), wages are considered to be determinants of the outsourcing decision. Therefore the main contractor may seek to subcontract production to take advantage of lower wages in subcontracting firms. If firms outsource in order to reduce costs relative to in-house production, we would expect that those firms where the labour costs are higher to be more active in outsourcing strategy. To test the relevance of the labour cost-saving motive for outsourcing, Girma and Görg (2004) include the wage rates for skilled and unskilled workers. However, they do not obtain conclusive results. Görg and Hanley (2004) do not find either a statistically significant effect of the average wage per employee. Instead of these results, Holl (2008) obtains a positive and significant coefficient between outsourcing and wages as well as Díaz-Mora (2007) who relates outsourcing to unit labour costs.

Other determinants of outsourcing decision such as firm size, degree of product differentiation and industry size are also proposed by Grossman and Helpman (2005). Like mentioned above, outsourcing implies search costs because intermediate producers and final-good producers have to search for each other. These search costs are influenced by firm size of the final-good producer. In this sense, Tomiura (2005) 
suggests that smaller firms could face higher search costs. That is, large firms with stronger market power might find contracting partners more easily. Furthermore, taking into account that outsourcing increases firm's capacity for adaptation and flexibility, it can be argued that large firms are more likely to carry out this process of vertically de-integration of production structures. The cost advantages due to economies of scale in the production of intermediate inputs must be considered (Abraham and Taylor, 1996) and a positive relationship between firm size and outsourcing is expected. However, small and medium enterprises, which usually experience more difficulties to reap the minimum efficient scale, could also do outsourcing more intensively. Firm size variable is used as a proxy for scale and scope economies. Moreover, the sign of firm size cannot be predicted a priori. While positive coefficients are highlighted in some previous empirical studies (Holl, 2008), others do not obtain a significant coefficient for firm size (Kimura, 2001).

The degree of output differentiation plays a key role in determining outsourcing decision, affecting the number of specialized intermediate producers that are operating in a specific industry. The less differentiated the products elaborated by the final-good producer are, the greater the chance to find the right partner and to emerge a stable outsourcing equilibrium is ${ }^{9}$. In order to consider this argument, a product differentiation variable is deployed. It is a dummy variable which takes value 1 if the firm offers a product specifically designed for the customer (a differentiated product) and 0 otherwise.

Since transaction costs are related to the search of suitable subcontracting partners, an important determinant of transaction costs is the thickness of the market

\footnotetext{
${ }^{9}$ In fact, Grossman and Helpman (2002) point out that the degree of product differentiation can influence outsourcing in other ways. But in this case, the effect on outsourcing can be positive or negative depending on other parameters. The net effect of product differentiation on outsourcing is therefore not clear.
} 
(Spencer, 2005). According to theoretical models, the size of the market is related to outsourcing. Grossman and Helpman (2002) and McLaren (2000) consider the effects of market thickness on the outsourcing of intermediate inputs when the trade-off between vertical integration and outsourcing is investigated. A thicker market increases the chance of finding a good external supplier reducing the advantage of vertical integration and making outsourcing more viable in large industries (Grossman and Helpman, 2002) ${ }^{10}$ and in firms operating in markets and economies open to international trade (McLaren, 2000). Both characteristics raise the chance to find a specialized provider, increasing the opportunities to engage in outsourcing ${ }^{11}$. The industry size is measured in two ways: by the number of firms in each industry (Industry-size1) and by the employment in each industry (Industry-size2). The level of internationalization is measured by a dummy variable which takes value 1 if the firm shows positive export behaviour and 0 otherwise.

Similar arguments can be used to consider the firm age as a determinant of subcontracting. More mature firms could find suitable subcontractors more easily due to a "learning effect" as well as incentives to focus on their core activities (Ono, 2003; Holl, 2008). Age is measured as the number of years the firm has been operating. It is computed as the difference between the current year of the survey and the year the firm was born.

Although cost-savings motive, specialization and scale economies explain a large part of outsourcing, changes in demand and other market conditions need to be

\footnotetext{
${ }^{10}$ In fact, these authors remind us that outsourcing is more likely to be viable, the larger is the industry and the larger the economy. If there are increasing returns in search, there can be two stable equilibria for an industry, one with vertical integration and the other with outsourcing.

${ }^{11}$ The role of firm internationalization on outsourcing decision will be relevant mainly when foreign outsourcing prevails. Although our data source does not let us distinguish between domestic and foreign outsourcing, other empirical research for Spanish economy using input-output tables show how the second one registers the greatest increase in recent years (Gandoy and Díaz-Mora, 2008), particularly in export-orientated industries.
} 
considered to provide a full perspective on what is happening (Demsetz, 1995; Abraham and Taylor, 1996; Shy and Stenbacka, 2003; Lin and Tsai, 2005; Buehler and Haucap, 2006). The more frequent these changes occur, the more necessary outsourcing strategy becomes in order to obtain higher flexibility. Outsourcing turns some fixed costs into variable costs allowing a greater flexibility for firms. A variable measuring changes in the market conditions is introduced as factor that leads firms to subcontract. Specifically, the following changes in the market conditions are considered: changes in own output prices, changes in national competitors' prices, changes in prices of similar imported products, entry of new players, increase or decrease in demand and changes in the market due to other reasons. They are measured as a dummy variable coded 1 if the surveyed firm reports a change in some of the above market conditions and 0 if does not. Holl (2008) includes a dummy variable to control for demand variations but she only focuses on the changes in the market share of the firm.

Moreover, as Lin and Tsai (2005) point out, a changing market environment increases the search for flexibility and the emphasis on core competences, offering an explanation for the growing outsourcing activities, in particular, when the products are characterized by a higher technological content ${ }^{12}$. In this sense, subcontracting is a way of flexible mode of production which allows them to take advantage of specialized producers. Firms focus on R\&D, design and other skill intensive stages of production and they subcontract most of their physical production. Therefore, subcontracting is becoming very important in firms producing sophisticated and high

\footnotetext{
${ }^{12}$ Demsetz (1995) reminds the role of technological change and, therefore, of the uncertainty on outsourcing decisions. Outsourcing will be more significant in high-tech products (due to technological change) as well as in sectors such as wearing apparel (due to changing fashion).
} 
tech goods (Curzon Price, 2001) ${ }^{13}$. To take into account this argument, we introduce dummy variables which take value 1 if the firm invests in $R \& D$ or does process or product innovation, expecting a positive relation between these firm's characteristics and the propensity to contract out production. These variables are hardly included in previous empirical research about determinants of subcontracting. Only Tomiura (2005, 2007) considers the variable R\&D expenditures as proxy for technological complexity obtaining that outsourcing is positively related to $R \& D$ effort.

The subcontracting decision could also depend on other variables. Shy and Stenbacka (2003) and Buehler and Haucap (2006) argue that firms use outsourcing as a strategic instrument to compete with their rivals in the industry where they operate. When outsourcing is considered as a competitive strategy, the higher the market competition, the higher the use of subcontracting is. To proxy the market competition, we use a dummy variable which takes value 1 if the firm has competitors with a significant quota in the own market and 0 otherwise. Additionally, taking into account the strategic motive for outsourcing, firms could be more prone to subcontracting in sectors where subcontracting is more frequent. Moreover, there can be specific sectoral characteristics which allow an easier disintegration of production processes favouring subcontracting. The introduction of industry dummies allows to control for technological heterogeneity as well as other permanent differences across industries.

An additional factor to consider in a model of the determinants of outsourcing is the foreign ownership that could affect the degree to which a firm engages in subcontracting. To control for nationality (foreign or domestic), we include the dummy variable Foreign-own which takes on value 1 if the firm has foreign

\footnotetext{
${ }^{13}$ The author includes another type of firms where subcontracting is growing: firms producing goods not very sophisticated or difficult to make, where the labour-intensive stages of production are contracted out. These firms suffer a strong competence by low wage areas and they use subcontracting for cut-cutting motives. For them, wage is a determinant of subcontracting.
} 
ownership participation (at least 50\%) and 0 otherwise. Previous work suggests a positive relation between international outsourcing and foreign ownership. Since foreign firms are part of an international network competing in a global market, the potential to contract out to more efficient producers abroad increases (Görg and Hanley, 2004; Girma and Görg, 2004). Preceding analysis about outsourcing decision has obtained positive signs (Kimura, 2001) but also negative signs (Holl, 2008). In the latter case, it can be argued that if foreign affiliates are located in a country just for doing production tasks for the parent company, the possibility from these manufacturing plants for using subcontractors could decrease. Therefore, the effect of foreign ownership on subcontracting is ambiguous and it will be an empirical issue.

\section{The Empirical Model}

The definition and expected sign of the variables included as determinants of subcontracting in our model are summarized in Table 2. Table 3 reports the means of the explanatory variables for firms that subcontract and firms that do no subcontract along the period. Substantial differences between the two types of firms can be observed. Firms which contract out production are larger; more mature, pay higher wages and belong to bigger industries than integrated firms. Moreover, the percentage of firms that face changes in market conditions invest in $R \& D$, obtain product and process innovation, offer a differentiated product, export, have competitors with a significant market quota and are participated by foreign capital is higher among firms which outsource production. Differences across firms depending on the type of subcontracting arrangement are also shown. 
We propose the following model to estimate the influence of diverse plant, industry and market characteristics on firm's subcontracting behaviour. These characteristics try to capture the above motives for firms to engage in production subcontracting:

$\operatorname{Pr}\left(\operatorname{SUBC}_{i t}=1\right)=F\left(\beta_{1}\right.$ SUBC $_{i, t-1}+\beta_{2}$ Wage $_{i, t-1}+\beta_{3}$ Firm-Size $_{i, t-1}+\beta_{4}$ Product-differentiation $_{i, t-1}$ $+\beta_{5}$ Industry-size $_{i, t-1}+\beta_{6}$ Export $_{i, t-1}+\beta_{7}$ Age $_{i t}+\beta_{8}$ Market-changes $_{i, t-1}+\beta_{9}$ Product-innovation $_{i, t-}$ ${ }_{1}+\beta_{10}$ Process-innovation $_{i, t-1}+\beta_{11} R \& D_{i, t-1}+\beta_{12}$ Market-competition $_{i, t-1}+\beta_{13}$ Foreign-own $_{i, t-1}$ $\left.+\beta_{14} D_{t}+\beta_{15} D_{j}+u_{i t}\right)$

Where $i$ represents the firm and $t$ is the year from 1991 to 2002. The dependent variable, the subcontracting decision $(S U B C)$, is a dichotomous variable which takes value 1 or 0 depending on whether the firm decides to contract out production in period $t$ or not. Since the direction of causality could remain uncertain for some of the explanatory variables, we lag them one period to avoid a potential simultaneity problem.

To test the determinants of subcontracting behaviour, we use a dynamic panel data probit model which includes the information available on the firm's probability to contract out production. It is a dynamic model because the lagged endogenous variable is included as an explanatory variable. Moreover, unobserved characteristics are likely to affect the decision to contract out production by the firm. This means that the error term, $u_{i t}$, comprises two components, a permanent unobserved plant-specific element $\left(\alpha_{i}\right)$ and the remainder disturbance $\left(v_{i t}\right)$. The firm-specific unobserved heterogeneity must be taken into account because in the case of being permanent or highly serially correlated, it can induce persistence in subcontracting behaviour, overestimating the coefficient on the lagged endogenous variable and thus incorrectly being interpreted as high entry cost (Bernard and Jensen, 2004). For this reason, we 
use a random effects probit model as well as a pooled probit. The random effects model requires that the unobserved firm effects be uncorrelated with the regressors, that is, uncorrelated with those firm characteristics which are observed and included in our subcontracting decision model. Nevertheless, random effects model can be adequate when a large population of firms are being sampled. In this case, the random effects estimation assumes that the unobserved firm characteristics are randomly distributed among the different transversal observations (Greene, 2000). Therefore, we test Equation 1 using pooled probit and random effects probit models and we compare the results. In the random effects probit model the individual unobserved effects are assumed to be independent of covariates. This assumption is quite likely violated as firm characteristics such as size or wage will also be related to unobserved attributes such as managerial ability, financing behaviour or capital structure that can also affect the decision to subcontract. If individual effects and covariates are indeed correlated, the effect of persistence and unobserved heterogeneity are not well distinguished. We therefore also estimate a Mundlak-Chamberlain random effects model, which allows for some correlation between explanatory variables and unobserved heterogeneity and obtain consistent estimates (Wooldridge, 2002).

\section{Estimation Results}

Table 4 displays the econometric results. Our data set consists of about 1550 firms yielding 17000 observations (depending of the specification). The results of the four first columns are based on the standard probit model where the observations are pooled over the sample period. The first column reports the results of the estimation of Equation 1 excluding the dummy variable for product differentiation. The coefficient estimates show signs and levels of significance in line with our expectations. Corresponding to the assumption that firms face entry costs when they decide to 
subcontract production, the coefficient for lagged subcontracting decision is positive and highly significant. Firm current decision to outsource depends on previous subcontracting behaviour. Moreover, in line with our prior expectations, firms paying higher wages are more likely to engage in subcontracting ${ }^{14}$. These firms tend to use outsourcing as a defensive strategy trying to improve their competitiveness. The positive and significant coefficient of wages provides empirical evidence of the costcutting motive for outsourcing.

Related to the variables used to capture the thickness of the market, only the exporter status shows positive and significant coefficients. Exporter firms are more likely to be main contractors ${ }^{15}$. The positive correlation is explained by a higher probability to find suitable providers. Neither the number of firms (industry-size1) nor the firm age are significant. Additionally, according to the positive link between the market changes and subcontracting behaviour, as the variations in market conditions are more frequent, the probability to outsource increases. This outcome confirms the hypothesis that outsourcing production is a strategy to gain flexibility in a context of rapid market changes. Our results confirm that firms involved in R\&D activities, product and process innovations (and product differentiation) are more prone to contract out production. In this sense, producing high-tech, differentiated and innovating products increases the firm's probability of subcontracting. As it has been argued above, these firms need to concentrate in their innermost core competences since they face a changing market environment. The coefficient for marketcompetition is positive and significant. Nevertheless, variables such as firms' size and

\footnotetext{
${ }^{14}$ As we explained above, we use one period lagged wages. Nevertheless, since the subcontracting decision is already included lagged one period in the model, we have considered the value of wages in $\mathrm{t}-2$ obtaining very similar estimation results. Results are available from the authors upon request

${ }^{15}$ This argument is used by Görg et al. (2004) who study the impact of international outsourcing on productivity employing plant-level data for Irish manufacturing. Their results show that exporting firms obtain more productivity gains from international outsourcing of materials inputs than non-exporter firms. The authors argue that exporting firms face lower costs of searching for potential suppliers abroad.
} 
foreign ownership exhibit an absence of statistical significance ${ }^{16}$. At last, most of the time and industry dummy variables are highly significant although, in order to spare space, the coefficients are omitted.

Table 4 also displays the estimations of three additional specifications. In the second specification (column 2), the variable firm size measured by the log of number of employees is substituted by two dummy variables. The first one (Dfirm-Sizel) takes value 1 if the firm has between 26 and 200 employees and 0 otherwise and the second one (Dfirm-Size2) takes value 1 if the firm has more than 200 employees and 0 otherwise. Both of them show insignificant coefficients. Firm size is not a determinant for the subcontracting decision. The sign and significance of the remainder regressors do not change.

Taking into account the lack of significance of the variable Industry-sizel (number of firms in each industry), we introduce the variable Industry-size2 (number of employees in each industry) in the column 3. It turns out statistically significant. As the industry-size increases, so do subcontracting decision. Again, the remainder regressors do not change. As the industry-size enlarges, so the probability of subcontracting decision increases.

The column 4 reports the results of the estimation adding the product differentiation as an explanatory variable. The product differentiation affects positively and significantly to the probability to subcontract. Variables such as market-changes and process-innovation loose their statistical significance, whereas

\footnotetext{
${ }^{16}$ We have also included the quadratic value of age and size in the regression to allow for a more flexible form, but the coefficients remain statistically insignificant.
} 
the coefficient for foreign ownership shows a negative and significant sign. The rest of the coefficients hardly change $\mathrm{e}^{17}$.

Table 4 also reports the estimation results using random-effects probit techniques (four last columns). We again distinguish the same four specifications and the results are very similar to earlier results. The only difference is that the dummy variable for firm size which takes value 1 if the firm has more than 200 employees turns out significant. That is, large firms are more prone to subcontract production than medium-sized and small firms.

Table 5 reports the marginal effects of the four specifications using pooled probit and random effects probit. They show how marginal changes in the independent variables would affect the predicted probabilities to decide subcontracting. Marginal effects of lagged subcontracting decision on current subcontracting probabilities are particularly large: firms that decided to subcontract production in the previous year have at least a $55 \%$ greater probability of doing subcontracting in current period. Marginal increases in the other explanatory variables also raise the probability that a firm subcontracts but the effect is lower. To conserve space, we only report values of marginal effects over all observations for significant explanatory variables ${ }^{18}$. Finally, we estimate a Mundlak-Chamberlain random effects model. Although the export and process innovation reduce their significance, all the results are comparable with the previous specifications (Table 6).

\footnotetext{
${ }^{17}$ The presence of yearly and quadrennial variables is due to the different nature of the information collected in the ESEE. Product differentiation is only asked every four years to firms and we use only the available information. For more information, see http://www.funep.es/esee/ing/i_esee.asp.

${ }^{18}$ The regressions were also run separately for each subsample of firms: firms subcontracting providing materials and firm subcontracting without materials. But the sign and significance of the coefficients of variables are similar to those obtained for aggregate subcontracting. Two particularities need to be mentioned. First, the estimates for subcontracting providing materials show that size has a significant and positive effect on subcontracting decision. For this type of subcontracting, the likelihood of subcontracting increases with the size of the firm. Second, the econometric findings for subcontracting without materials suggest that age is an important factor in the propensity to engage in contracting out. More mature firms are more prone to subcontract production without providing materials.
} 


\section{Final Considerations}

This article has estimated a model of the determinants of outsourcing decision using firm-level manufacturing data from 1991 to 2002. Our empirical analysis shows that almost one in every two manufacturing firms has been engaged in outsourcing along the period. We also point out that the outsourcing decision seems to be influenced by firm size and industry-specific characteristics being more frequent in large firms and in sectors such as Machinery and mechanical goods, Office and electrical equipment, Transport equipment, Textiles and clothing and Editing and printing.

Following theoretical and empirical literature, we estimate a model where firm, industry and market characteristics influence the likelihood of contracting out. Moreover, we consider that transaction costs are a key difficulty in adopting outsourcing strategy (Grossman and Helpman, 2002). This would explain that around half of surveyed firms are inactive in subcontracting. Furthermore, the presence of these costs (partially sunk costs) would imply persistence in the outsourcing decision. In effect, we observe a high persistence of participation decision in subcontracting from one year to the next. So, in our model we also include the lagged dependent variable as a regressor. Using a dynamic panel data probit model, our results indicate that previous subcontracting experience, wages, product differentiation, industry and firm size, exporter status, product differentiation, market changes, R\&D activities and product and process innovation clearly favour engaging in outsourcing.

On the one hand, the significance of variables such as wages, market changes, product differentiation and $R \& D$ and innovation activities emphasizes the reasons for outsourcing. Firms decide to outsource not only for cutting labour costs but also for 
gaining flexibility and dynamism and for strengthening their core competences. On the other hand, the significance of the rest of the variables point out the difficulties in becoming an outsourcer. Previous outsourcing experience, large size and exporting seem to be prerequisites for outsourcing activities because they allow to reduce outsourcing entry costs like those associated with finding suitable providers. In this sense, policies designed to decrease these entry costs in order to facilitate contacts between outsourcers and providers could be adequate. An example of this kind of initiative is the SCAN (e.g. subcontracting assistant network) project developed by the European Commission in the 1990's. These initiatives which help to shrink the entry barriers to outsourcing, encouraging it, are particularly necessary for smaller and domestic-oriented firms.

\section{Acknowledgements}

The authors are indebted to Rosario Gandoy for helpful suggestions. Financial support by the Consejería de Educación y Ciencia of the Junta de Comunidades de Castilla-La Mancha under the project PBI-05-021, co-financed by FEDER funds, is gratefully acknowledged.

\section{$\underline{\text { References }}$}

Abraham, K. and Taylor, S. (1996) Firm's use of outside contractors, theory and evidence, Journal of Labour Economics, 14, 394-424.

Antras, P. and Helpman, E. (2004) Global outsourcing, Journal of Political Economy, 112, 552-580.

Bernard, A. B. and Jensen, B. (2004) Why some firms export, Review of Economics and Statistics, 86, 561-569. 
Buehler, S. and Haucap, J. (2006) Strategic outsourcing revisited. Journal of Economic Behaviour and Organization, 6, 325-338.

Curzon Price, V. (2001) Some causes and consequences, in Fragmentation. New production patterns in the world economy (Eds.) S.W. Arndt and H. Kierzkowski, Oxford University Press, Oxford, pp. 88-107.

Demsetz, H. (1995) The Economics of the business firm, seven critical commentaries, Oxford University Press, Oxford.

Díaz-Mora, C. (2007) What factors determine the outsourcing intensity? A dynamic panel data approach for manufacturing industries, Applied Economics, 40, 2509-2521.

Gandoy, R. and Díaz-Mora, C. (2008) El Offshoring en la industria española, una revisión de la evidencia empírica. Información Comercial Española, 387, 195-210.

Girma, S. and Görg, H. (2004) Outsourcing, foreign ownership and productivity, evidence from UK establishment level data, Review of International Economics, 12, 817-832.

Görg, H. and Hanley, A. (2004) Does outsourcing increase profitability?, The Economic and Social Review, 35, 367-387.

Görg, H., Hanley, A. and Strobl, E. (2004) Outsourcing, foreign ownership, exporting and productivity, an empirical investigation with plant level data, Research Paper 08, mimeo, University of Nottingham, Nottingham.

Greene, W. H. (2000) Econometric analysis, Prentice-Hall, London.

Grossman, G.M. and Helpman, E. (2002) Integration versus outsourcing in industry equilibrium, Quarterly Journal of Economics 117, 85-120. 
Grossman, G.M. and Helpman, E. (2005), Outsourcing in a global economy, The Review of Economic Studies 72, 135-160.

Holl, A. (2008) Production subcontracting and location, Regional Science and Urban Economics, 38, 299-309.

Kimura, F. (2001) Fragmentation, internalization, and interfirm linkages, Evidence from the micro data of Japanese manufacturing firms. In Global production and trade in East Asia, (Eds.) L.K. Cheng and H. Kierzkowski, Kluwer Academic Publishers, Boston, pp, 129-152.

Kimura, F. and Ando, M. (2005) Two-dimensional fragmentation in East Asia, conceptual framework and empirics, International Review of Economics and Finance, 14, 317-348.

Lin, J.Y. and Tsai, Y. (2005) What's new about Outsourcing?, Unpublished paper presented to the Pacific Asia Free Trade and Development $30^{\text {th }}$ Conference, mimeo, Honolulu, Hawai.

McLaren, J. (2000) Globalization and Vertical Structure, American Economic Review, 90, 1239-1254.

Ono, Y. (2003) Outsourcing business services and the role of central administrative offices, Journal of Urban Economics, 53, 377-395.

Shy, O. and Stenbacka, R. (2003) Strategic outsourcing, Journal of Economic Behaviour and Organization, 50, 203-224.

Spencer, B. (2005) International Outsourcing and Incomplete Contracts, Canadian Journal of Economics, 38, 1107-1135. 
Swenson, D. L. (2004) Entry costs and outsourcing decisions, evidence from the U.S. overseas assembly provision, North American Journal of Economics and Finance, 15, 267-286.

Tomiura, E. (2005) Foreign outsourcing and firm-level characteristics, evidence from Japanese manufacturers, Journal of the Japanese and International Economics. 19, 255-271.

Tomiura, E. (2007) Global Sourcing, technology and factor intensity, firm-level relationships. RIETI Discussion Paper Series 07-E-024, mimeo, Department of Economics, Yokohama National University, Japan.

Wooldridge, J.M. (2002) Econometric Analysis of Cross Section and Panel Data, MIT Press, Cambridge, Massachusets.

World Trade Organization (2005) World Trade Report 2005 in Chapter 3C, Offshoring services, recent development and prospects, Geneva, pp. 265-294.

Fig. 1. Evolution of outsourcing decision by size

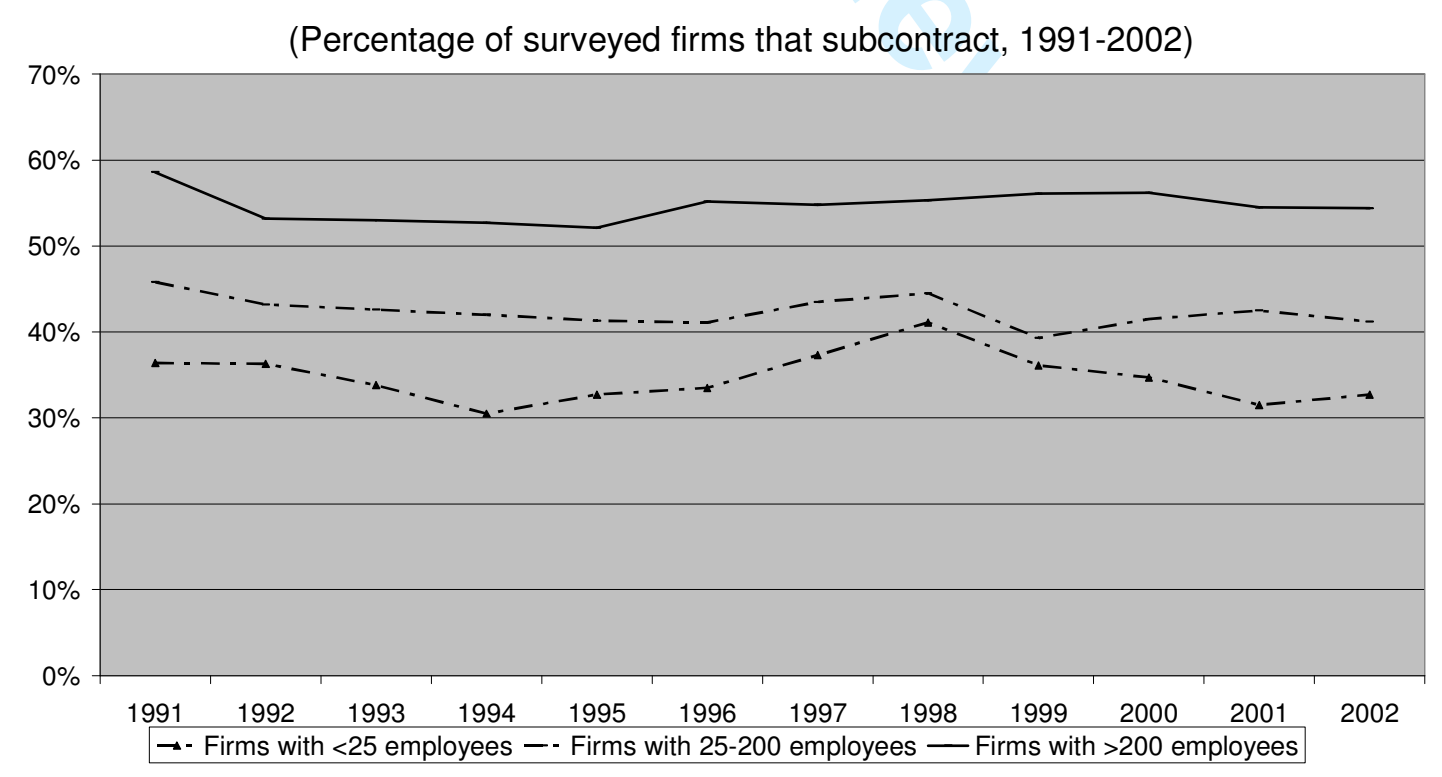

Source: ESEE 
Fig. 2. Outsourcing decision by industry

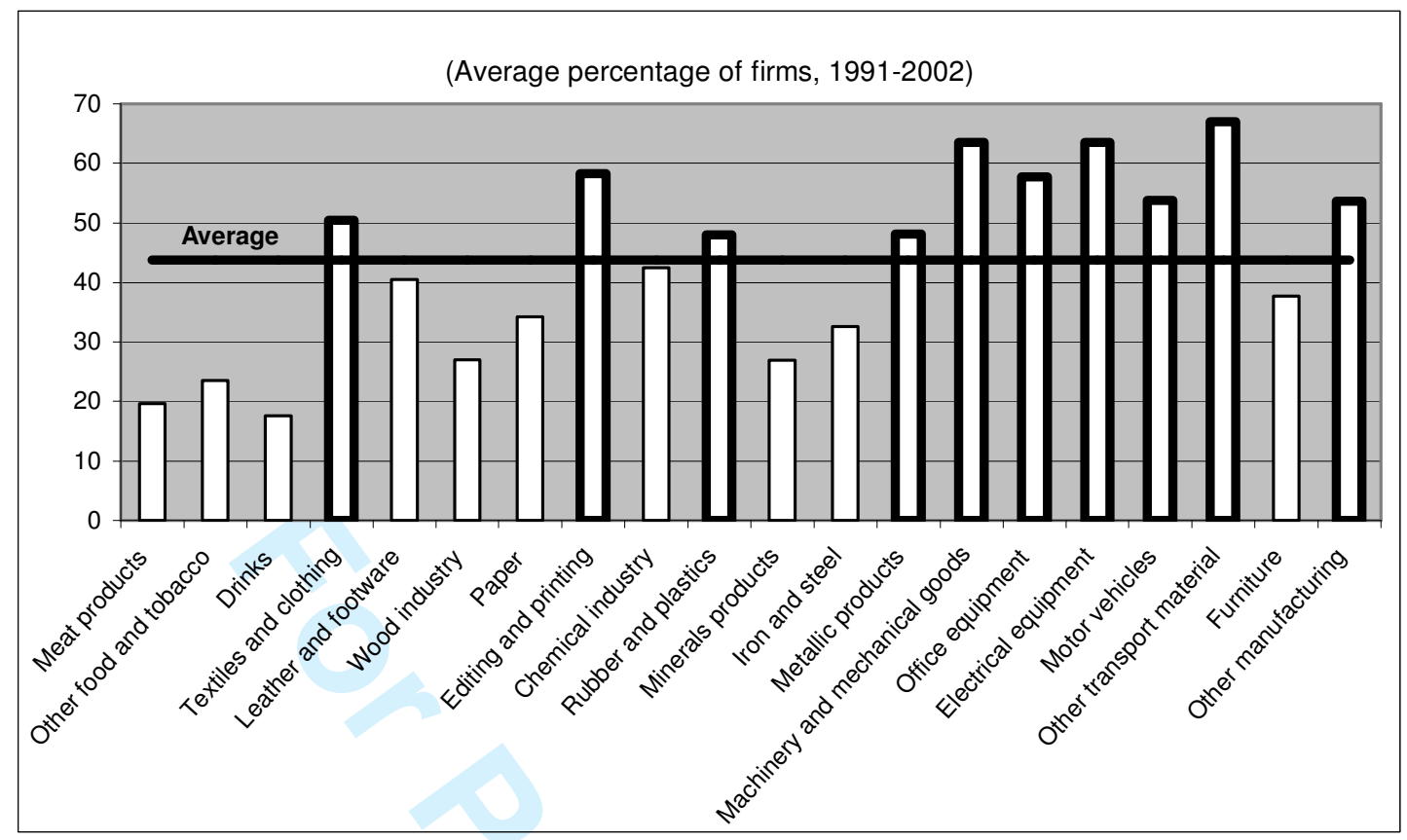

Source: ESEE

Table 1. Outsourcing transition probabilities by industry

\begin{tabular}{|l|c|c|c|c|}
\hline \multirow{2}{*}{\multicolumn{1}{|c|}{ Industries }} & \multicolumn{2}{|c|}{ Positive Subc. in current year } & \multicolumn{2}{c|}{ Not Subc. in current year } \\
\cline { 2 - 5 } & \multicolumn{2}{|c|}{$\mathrm{t}+1$ probabilities } & \multicolumn{2}{c|}{$\mathrm{t}+1$ probabilities } \\
\cline { 2 - 5 } & Subc. $\mathrm{t}+1$ & No-Subc. $\mathrm{t}+1$ & Subc. $\mathrm{t}+1$ & No-Subc. $\mathrm{t}+1$ \\
\hline Meat products & 66.67 & 33.33 & 8.06 & 91.94 \\
Other food and tobacco & 76.20 & 23.80 & 7.44 & 92.56 \\
Drinks & 64.18 & 35.82 & 7.55 & 92.45 \\
Textiles and clothing & 85.71 & 14.29 & 13.88 & 86.12 \\
Leather and footwear & 77.92 & 22.08 & 13.99 & 86.01 \\
Wood industry & 65.08 & 34.92 & 12.80 & 87.20 \\
Paper & 79.35 & 20.65 & 9.79 & 90.21 \\
Editing and printing & 82.48 & 17.52 & 23.48 & 76.52 \\
Chemical industry & 83.52 & 16.48 & 11.59 & 88.41 \\
Rubber and plastics & 83.08 & 16.92 & 15.69 & 84.31 \\
Minerals products & 71.51 & 28.49 & 10.48 & 89.52 \\
Iron and steel & 77.08 & 22.92 & 10.53 & 89.47 \\
Metallic products & 77.81 & 22.19 & 18.05 & 81.95 \\
Machinery and mechanical goods & 86.51 & 13.49 & 21.67 & 78.33 \\
Office equipment & 85.88 & 14.12 & 19.17 & 80.83 \\
Electrical equipment & 88.09 & 11.91 & 22.08 & 77.92 \\
Motor vehicles & 84.08 & 15.92 & 17.39 & 82.61 \\
Other transport material & 83.87 & 16.13 & 27.97 & 72.03 \\
Furniture & 73.82 & 26.18 & 16.85 & 83.15 \\
Other manufacturing & 87.34 & 12.66 & 14.21 & 85.79 \\
\hline Total manufacturing industry & $\mathbf{8 1 . 6 5}$ & $\mathbf{1 8 . 3 5}$ & $\mathbf{1 3 . 7 3}$ & $\mathbf{8 6 . 2 7}$ \\
\hline
\end{tabular}

Source: ESEE 
Table 2. Explanatory variables: definition and expected signs.

\begin{tabular}{|c|c|c|}
\hline Variable & Definition & Expected sign \\
\hline Subct-1 & $\begin{array}{l}\text { Dummy variable that takes the value } 1 \text { if the firm } \\
\text { subcontracted production in } \mathrm{t}-1 \text { and } 0 \text { otherwise }\end{array}$ & \\
\hline Wage & Log of the wage per employee & + \\
\hline Firm-Size & $\begin{array}{l}\text { Firm size measured by the log of the number of } \\
\text { workers }\end{array}$ & Undetermined \\
\hline $\begin{array}{l}\text { Product- } \\
\text { differentiation }\end{array}$ & $\begin{array}{l}\text { Dummy variable that takes the value } 1 \text { if the firm offers } \\
\text { a differentiated product and } 0 \text { otherwise }\end{array}$ & Undetermined \\
\hline Industry-Size & $\begin{array}{l}\text { Log of the number of firms (or employees) in the } \\
\text { industry }\end{array}$ & + \\
\hline Export & $\begin{array}{l}\text { Dummy variable that takes the value } 1 \text { if the firm } \\
\text { exports and } 0 \text { otherwise }\end{array}$ & + \\
\hline Firm Age & $\begin{array}{l}\text { Firm's age measured by the log of the number of } \\
\text { years since the firm was born }\end{array}$ & + \\
\hline Market-changes & $\begin{array}{l}\text { Dummy variable that takes the value } 1 \text { if the firm has } \\
\text { suffered changes in market conditions and } 0 \text { otherwise }\end{array}$ & + \\
\hline Product-innovation & $\begin{array}{l}\text { Dummy variable that takes the value } 1 \text { if the firm does } \\
\text { product innovation and } 0 \text { otherwise }\end{array}$ & + \\
\hline Process-innovation & $\begin{array}{l}\text { Dummy variable that takes the value } 1 \text { if the firm does } \\
\text { process innovation and } 0 \text { otherwise }\end{array}$ & + \\
\hline$R \& D$ & $\begin{array}{l}\text { Dummy variable that takes the value } 1 \text { if the firm does } \\
\text { invest in } R \& D \text { and } 0 \text { otherwise }\end{array}$ & + \\
\hline Market-competition & $\begin{array}{l}\text { Dummy variable that takes the value } 7 \text { if the firm nas } \\
\text { competitors with a significant market quota and } 0 \\
\text { otherwise }\end{array}$ & + \\
\hline Foreign-own & $\begin{array}{l}\text { Dummy variable that takes the value } 1 \text { if the firm has } \\
\text { foreign capital participation and } 0 \text { otherwise }\end{array}$ & Undetermined \\
\hline Dj & Industry dummies for 20 sectors of two-digit NACE & \\
\hline Dt & Time dummies & \\
\hline
\end{tabular}

Table 3: Firm, industry and market characteristics and subcontracting

\begin{tabular}{|l|c|c|}
\cline { 2 - 3 } \multicolumn{1}{l|}{} & $\begin{array}{c}\text { Firms that } \\
\text { subcontract }\end{array}$ & $\begin{array}{c}\text { Firms that do } \\
\text { not } \\
\text { subcontract }\end{array}$ \\
Firm size (number of employees) & 24591 & 22284 \\
Product differentiation (\% of firms that offer it) & 357 & 208 \\
Industry-Size1 (number of firms) & $42.7 \%$ & $33.0 \%$ \\
Industry-Size2 (number of employees) & 120 & 119 \\
Export status (\% of firms that export) & 350709 & 338173 \\
Firm age (number of years) & $72.2 \%$ & $51.5 \%$ \\
Market changes (\% of firms that face to them) & 25 & 22 \\
Product innovations (\% of firms that do them) & $33.8 \%$ & $29.6 \%$ \\
Process innovations (\% of firms that do them) & $36.3 \%$ & $20.3 \%$ \\
R\&D activities (\% of firms that do them) & $42.3 \%$ & $30.2 \%$ \\
Market competition (\% of firms with competitors & $47.4 \%$ & $29.1 \%$ \\
with a relevant market quota) & $82.9 \%$ & $77.5 \%$ \\
Foreign ownership (\% of firms with foreign & & \\
capital participation) & $27.4 \%$ & $19.9 \%$ \\
\hline
\end{tabular}

Source: ESEE 
Table 4. Regression results (Dynamic panel data probit estimation)

(Dependent variable: Subcontracting decision)

\begin{tabular}{|c|c|c|c|c|c|c|c|c|}
\hline \multirow[b]{2}{*}{ Coefficients } & \multicolumn{4}{|c|}{ Pooled probit } & \multicolumn{4}{|c|}{ Random effects probit } \\
\hline & $(1)$ & (2) & (3) & $(4)$ & $(1)$ & $(2)$ & (3) & (4) \\
\hline Subct-1 $_{t-1}$ & $\begin{array}{l}1.862^{\star * *} \\
(0.024)\end{array}$ & $\begin{array}{l}1.861^{* * *} \\
(0.024)\end{array}$ & $\begin{array}{l}1.861^{* * *} \\
(0.024)\end{array}$ & $\begin{array}{l}1.726^{* * *} \\
(0.045)\end{array}$ & $\begin{array}{l}1.514^{* * *} \\
(0.033)\end{array}$ & $\begin{array}{l}1.513^{* * *} \\
(0.033)\end{array}$ & $\begin{array}{l}1.513^{* * *} \\
(0.033)\end{array}$ & $\begin{array}{l}1.856^{* * *} \\
(0.059)\end{array}$ \\
\hline Wage $_{t-1}$ & $\begin{array}{l}0.150^{\star * *} \\
(0.037)\end{array}$ & $\begin{array}{l}0.140^{* * *} \\
(0.036)\end{array}$ & $\begin{array}{l}0.141^{* * *} \\
(0.036)\end{array}$ & $\begin{array}{l}0.158^{* *} \\
(0.067)\end{array}$ & $\begin{array}{l}0.231^{* * *} \\
(0.049)\end{array}$ & $\begin{array}{l}0.223^{* * *} \\
(0.048)\end{array}$ & $\begin{array}{l}0.224^{* * *} \\
(0.048)\end{array}$ & $\begin{array}{l}0.188^{\star *} \\
(0.078)\end{array}$ \\
\hline Firm-size & $\begin{array}{l}-0.004 \\
(0.012)\end{array}$ & & & & $\begin{array}{l}0.012 \\
(0.017)\end{array}$ & & & \\
\hline Dfirm-size1 & & $\begin{array}{l}0.001 \\
(0.032)\end{array}$ & $\begin{array}{l}0.000 \\
(0.032)\end{array}$ & $\begin{array}{l}0.004 \\
(0.058)\end{array}$ & & $\begin{array}{l}0.027 \\
(0.044)\end{array}$ & $\begin{array}{l}0.025 \\
(0.044)\end{array}$ & $\begin{array}{l}0.017 \\
(0.068)\end{array}$ \\
\hline Dfirm-size2 & & $\begin{array}{l}0.041 \\
(0.043)\end{array}$ & $\begin{array}{l}0.040 \\
(0.043)\end{array}$ & $\begin{array}{l}0.074 \\
(0.081)\end{array}$ & & $\begin{array}{l}0.103^{*} \\
(0.061)\end{array}$ & $\begin{array}{l}0.101^{*} \\
(0.061)\end{array}$ & $\begin{array}{l}0.102 \\
(0.095)\end{array}$ \\
\hline Product-Differentiation & & & & $\begin{array}{l}0.163^{* * *} \\
(0.051)\end{array}$ & & & & $\begin{array}{l}0.190^{\star \star *} \\
(0.060)\end{array}$ \\
\hline Industry-size1 & $\begin{array}{l}-0.075 \\
(0.126)\end{array}$ & $\begin{array}{l}-0.081 \\
(0.126)\end{array}$ & & & $\begin{array}{l}-0.123 \\
(0.143)\end{array}$ & $\begin{array}{l}-0.130 \\
(0.143)\end{array}$ & & \\
\hline Industry-size2 & 28 & & $\begin{array}{l}0.180^{* * *} \\
(0.046)\end{array}$ & $\begin{array}{l}0.168^{*} \\
(0.091)\end{array}$ & & & $\begin{array}{l}0.289^{* \star *} \\
(0.071)\end{array}$ & $\begin{array}{l}0.191^{*} \\
(0.109)\end{array}$ \\
\hline Export & $\begin{array}{l}0.203^{* * *} \\
(0.030)\end{array}$ & $\begin{array}{l}0.196^{* * *} \\
(0.030)\end{array}$ & $\begin{array}{l}0.196^{* * *} \\
(0.030)\end{array}$ & $\begin{array}{l}0.226^{* * *} \\
(0.056)\end{array}$ & $\begin{array}{l}0.252^{* * *} \\
(0.041)\end{array}$ & $\begin{array}{l}0.245^{* * *} \\
(0.040)\end{array}$ & $\begin{array}{l}0.246^{* * *} \\
(0.040)\end{array}$ & $\begin{array}{l}0.247^{* * *} \\
(0.065)\end{array}$ \\
\hline Firm age & $\begin{array}{l}0.010 \\
(0.014)\end{array}$ & $\begin{array}{l}0.007 \\
(0.014)\end{array}$ & $\begin{array}{l}0.007 \\
(0.014)\end{array}$ & $\begin{array}{l}0.004 \\
(0.025)\end{array}$ & $\begin{array}{l}0.014 \\
(0.019)\end{array}$ & $\begin{array}{l}0.012 \\
(0.019)\end{array}$ & $\begin{array}{l}0.012 \\
(0.019)\end{array}$ & $\begin{array}{l}0.008 \\
(0.029)\end{array}$ \\
\hline Market-changes & $\begin{array}{l}0.067^{* *} \\
(0.026)\end{array}$ & $\begin{array}{l}0.065^{\star *} \\
(0.026)\end{array}$ & $\begin{array}{l}0.065^{\star *} \\
(0.026)\end{array}$ & $\begin{array}{l}-0.012 \\
(0.050)\end{array}$ & $\begin{array}{l}0.076^{\star *} \\
(0.031)\end{array}$ & $\begin{array}{l}0.075^{\star *} \\
(0.031)\end{array}$ & $\begin{array}{l}0.075^{\star *} \\
(0.031)\end{array}$ & $\begin{array}{l}-0.024 \\
(0.057)\end{array}$ \\
\hline Product innovation & $\begin{array}{l}0.178^{\star * *} \\
(0.030)\end{array}$ & $\begin{array}{l}0.178^{\star \star *} \\
(0.030)\end{array}$ & $\begin{array}{l}0.178^{* * *} \\
(0.030)\end{array}$ & $\begin{array}{l}0.171^{* * *} \\
(0.055)\end{array}$ & $\begin{array}{l}0.198^{* * *} \\
(0.036)\end{array}$ & $\begin{array}{l}0.197^{\star * *} \\
(0.036)\end{array}$ & $\begin{array}{l}0.197^{* * *} \\
(0.036)\end{array}$ & $\begin{array}{l}0.202^{* * *} \\
(0.063)\end{array}$ \\
\hline Process innovation & $\begin{array}{l}0.077^{\star \star \star} \\
(0.027)\end{array}$ & $\begin{array}{l}0.074^{\star \star \star} \\
(0.027)\end{array}$ & $\begin{array}{l}0.074^{* * *} \\
(0.027)\end{array}$ & $\begin{array}{l}0.075 \\
(0.050)\end{array}$ & $\begin{array}{l}0.085^{\star * *} \\
(0.032)\end{array}$ & $\begin{array}{l}0.083^{\star \star \star} \\
(0.032)\end{array}$ & $\begin{array}{l}0.083^{\star *} \\
(0.032)\end{array}$ & $\begin{array}{l}0.083 \\
(0.057)\end{array}$ \\
\hline$R \& D$ & $\begin{array}{l}0.090^{\star * \star} \\
(0.032)\end{array}$ & $\begin{array}{l}0.078^{\star *} \\
(0.031)\end{array}$ & $\begin{array}{l}0.079^{* \star} \\
(0.031)\end{array}$ & $\begin{array}{l}0.144^{\star \star} \\
(0.058)\end{array}$ & $\begin{array}{l}0.142^{\star * *} \\
(0.040)\end{array}$ & $\begin{array}{l}0.134^{\star \star \star} \\
(0.040)\end{array}$ & $\begin{array}{l}0.134^{\star \star *} \\
(0.040)\end{array}$ & $\begin{array}{l}0.173^{* * *} \\
(0.067)\end{array}$ \\
\hline Market-competition & $\begin{array}{l}0.058^{*} \\
(0.031)\end{array}$ & $\begin{array}{l}0.058^{*} \\
(0.031)\end{array}$ & $\begin{array}{l}0.058^{*} \\
(0.031)\end{array}$ & $\begin{array}{l}0.121^{\text {** }} \\
(0.057)\end{array}$ & $\begin{array}{l}0.062 \\
(0.039)\end{array}$ & $\begin{array}{l}0.063 \\
(0.039)\end{array}$ & $\begin{array}{l}0.063 \\
(0.039)\end{array}$ & $\begin{array}{l}0.142^{* *} \\
(0.066)\end{array}$ \\
\hline Foreign-own. & $\begin{array}{l}-0.049 \\
(0.034) \\
\end{array}$ & $\begin{array}{l}-0.060^{*} \\
(0.034) \\
\end{array}$ & $\begin{array}{l}-0.060^{*} \\
(0.034) \\
\end{array}$ & $\begin{array}{l}-0.112^{*} \\
(0.063) \\
\end{array}$ & $\begin{array}{l}-0.052 \\
(0.048) \\
\end{array}$ & $\begin{array}{l}-0.062 \\
(0.048) \\
\end{array}$ & $\begin{array}{l}-0.061 \\
(0.048) \\
\end{array}$ & $\begin{array}{l}-0.118 \\
(0.074) \\
\end{array}$ \\
\hline Observations & 16993 & 16993 & 16993 & 4848 & $\begin{array}{r}16993 \\
2553\end{array}$ & $\begin{array}{r}16993 \\
2553\end{array}$ & $\begin{array}{r}16993 \\
2553\end{array}$ & $\begin{array}{l}4848 \\
2428\end{array}$ \\
\hline Tvemider or groups & - & - & - & - & $\begin{array}{l}2000 \\
-\end{array}$ & - & -2000 & - \\
\hline Log likelihood & 7061.36 & 7060.68 & 7060.90 & 2112.33 & 6936.09 & 6934.69 & 6935.09 & 2098.16 \\
\hline LR test $(r h o=0)$ & 9212.84 & 9214.17 & 9213.76 & 2112.33 & 250.55 & 252.00 & 251.59 & 28.34 \\
\hline Prob>chi2 & 0.000 & 0.000 & 0.000 & 0.000 & 0.000 & 0.000 & 0.000 & 0.000 \\
\hline Pseudo R2 & 0.3948 & 0.3949 & 0.3948 & 0.3654 & & & & \\
\hline
\end{tabular}


Table 5. Marginal effects

(based on probit results of Table 4)

\begin{tabular}{|c|c|c|c|c|c|c|c|c|}
\hline & \multicolumn{4}{|c|}{ Pooled probit } & \multicolumn{4}{|c|}{ Random effects probit } \\
\hline Marginal effects & (1) & $(2)$ & (3) & (4) & $(1)$ & (2) & (3) & (4) \\
\hline Subct $_{t-1}$ & $\begin{array}{c}0.645^{\star * *} \\
(0.006)\end{array}$ & $\begin{array}{c}0.645^{\star \star \star} \\
(0.006)\end{array}$ & $\begin{array}{l}0.645^{\star \star \star} \\
(0.006)\end{array}$ & $\begin{array}{l}0.609^{* \star \star} \\
(0.012)\end{array}$ & $\begin{array}{c}0.547^{\star \star \star} \\
(0.010)\end{array}$ & $\begin{array}{c}0.547^{\star \star \star} \\
(0.010)\end{array}$ & $\begin{array}{c}0.547^{* \star \star} \\
(0.010)\end{array}$ & $\begin{array}{c}0.643^{\star \star \star} \\
(0.015)\end{array}$ \\
\hline Wage $_{t-1}$ & $\begin{array}{c}0.056^{* * *} \\
(0.014)\end{array}$ & $\begin{array}{c}0.052^{* * *} \\
(0.014)\end{array}$ & $\begin{array}{l}0.052^{\star * *} \\
(0.014)\end{array}$ & $\begin{array}{l}0.062^{* *} \\
(0.026)\end{array}$ & $\begin{array}{c}0.086^{* * *} \\
(0.019)\end{array}$ & $\begin{array}{c}0.083^{* * *} \\
(0.019)\end{array}$ & $\begin{array}{c}0.084^{\star * *} \\
(0.019)\end{array}$ & $\begin{array}{l}0.073^{* *} \\
(0.030)\end{array}$ \\
\hline Dfirm-size2 & & & & & & $\begin{array}{l}0.041^{*} \\
(0.024)\end{array}$ & $\begin{array}{l}0.039^{*} \\
(0.024)\end{array}$ & \\
\hline Product-Differentiation & & & & $\begin{array}{l}0.064^{* * *} \\
(0.020)\end{array}$ & & & & $\begin{array}{c}0.074^{* * *} \\
(0.023)\end{array}$ \\
\hline Industry-size2 & & & $\begin{array}{l}0.073^{* * *} \\
(0.018)\end{array}$ & $\begin{array}{l}0.066^{*} \\
(0.035)\end{array}$ & & & $\begin{array}{c}0.116^{* * *} \\
(0.028)\end{array}$ & $\begin{array}{l}0.074^{*} \\
(0.042)\end{array}$ \\
\hline Export & $\begin{array}{c}0.079^{\star \star * *} \\
(0.012)\end{array}$ & $\begin{array}{c}0.076^{* * *} \\
(0.012)\end{array}$ & $\begin{array}{l}0.076^{* * *} \\
(0.012)\end{array}$ & $\begin{array}{l}0.088^{* * *} \\
(0.021)\end{array}$ & $\begin{array}{c}0.096^{* * *} \\
(0.015)\end{array}$ & $\begin{array}{c}0.094^{* * *} \\
(0.015)\end{array}$ & $\begin{array}{c}0.094^{* * *} \\
(0.015)\end{array}$ & $\begin{array}{c}0.095^{\star * *} \\
(0.025)\end{array}$ \\
\hline Market-changes & $\begin{array}{c}0.027^{* * *} \\
(0.010)\end{array}$ & $\begin{array}{l}0.026^{* *} \\
(0.010)\end{array}$ & $\begin{array}{l}0.026^{* *} \\
(0.010)\end{array}$ & $\begin{array}{l}-0.005 \\
(0.019)\end{array}$ & $\begin{array}{l}0.030^{* *} \\
(0.012)\end{array}$ & $\begin{array}{l}0.030^{* *} \\
(0.012)\end{array}$ & $\begin{array}{l}0.030^{* *} \\
(0.012)\end{array}$ & \\
\hline Product innovation & $\begin{array}{c}0.070^{* * *} \\
(0.012)\end{array}$ & $\begin{array}{c}0.070^{\star * *} \\
(0.012)\end{array}$ & $\begin{array}{l}0.070^{* * *} \\
(0.012)\end{array}$ & $\begin{array}{l}0.067^{* * *} \\
(0.022)\end{array}$ & $\begin{array}{c}0.078^{\star * *} \\
(0.014)\end{array}$ & $\begin{array}{c}0.077^{\star * *} \\
(0.014)\end{array}$ & $\begin{array}{c}0.077^{* * *} \\
(0.014)\end{array}$ & $\begin{array}{c}0.079^{* * *} \\
(0.025)\end{array}$ \\
\hline Process innovation & $\begin{array}{c}0.028^{* * *} \\
(0.011)\end{array}$ & $\begin{array}{l}0.027^{\star *} \\
(0.011)\end{array}$ & $\begin{array}{l}0.027^{\star *} \\
(0.011)\end{array}$ & $\begin{array}{l}0.030 \\
(0.020)\end{array}$ & $\begin{array}{l}0.030^{\star *} \\
((0.013)\end{array}$ & $\begin{array}{l}0.030^{\star *} \\
((0.013)\end{array}$ & $\begin{array}{l}0.030^{* *} \\
((0.013)\end{array}$ & \\
\hline$R \& D$ & $\begin{array}{c}0.034^{\star \star *} \\
(0.012)\end{array}$ & $\begin{array}{l}0.030^{\star *} \\
(0.012)\end{array}$ & $\begin{array}{l}0.030^{\star \star} \\
(0.012)\end{array}$ & $\begin{array}{l}0.057^{\star *} \\
(0.023)\end{array}$ & $\begin{array}{c}0.054^{\star * *} \\
(0.016)\end{array}$ & $\begin{array}{c}0.051^{\star * *} \\
(0.016)\end{array}$ & $\begin{array}{c}0.051^{* \star *} \\
(0.016)\end{array}$ & $\begin{array}{c}0.068^{* \star *} \\
(0.026)\end{array}$ \\
\hline Market-competition & $\begin{array}{l}0.022^{*} \\
(0.012)\end{array}$ & $\begin{array}{c}0.022^{*} \\
(0.012)\end{array}$ & $\begin{array}{l}0.022^{*} \\
(0.012)\end{array}$ & $\begin{array}{l}0.047^{\star *} \\
(0.022)\end{array}$ & & & & $\begin{array}{c}0.055^{\star} \\
(0.025)\end{array}$ \\
\hline Fore & & & & $\begin{array}{l}-0.043^{*} \\
(0.024)\end{array}$ & & & & \\
\hline
\end{tabular}

Notes: Numbers in parenthesis are SE.

$*, * *, * *$ denotes test statistic significance at the $10 \%, 5 \%$ and $1 \%$ level, respectively. 
Table 6. Regression results (Mundlak-Chamberlain's Approach)

(Dependent variable: Subcontracting decision)

\begin{tabular}{|c|c|c|c|c|}
\hline \multirow[b]{2}{*}{ Coefficients } & \multicolumn{4}{|c|}{ Mundlak-Chamberlain Random effects probit } \\
\hline & Column (1) & Column (2) & Column (3) & Column (4) \\
\hline Subc $_{t-1}$ & $\begin{array}{l}1.465^{\star * *} \\
(0.036)\end{array}$ & $\begin{array}{l}1.464^{* * *} \\
(0.036)\end{array}$ & $\begin{array}{l}1.465^{\star * \star} \\
(0.036)\end{array}$ & $\begin{array}{l}1.854^{\star * \star} \\
(0.059)\end{array}$ \\
\hline Wage $_{t-1}$ & $\begin{array}{l}0.236^{* * *} \\
(0.064)\end{array}$ & $\begin{array}{l}0.234^{* * *} \\
(0.063)\end{array}$ & $\begin{array}{l}0.235^{\star * *} \\
(0.063)\end{array}$ & $\begin{array}{l}0.244^{* *} \\
(0.111)\end{array}$ \\
\hline Firm-size & $\begin{array}{l}-0.004 \\
(0.053)\end{array}$ & & & \\
\hline Dfirm-size1 & & $\begin{array}{c}0.012 \\
(0.047)\end{array}$ & $\begin{array}{l}0.011 \\
(0.047)\end{array}$ & $\begin{array}{l}-0.005 \\
(0.070)\end{array}$ \\
\hline Dfirm-size2 & & $\begin{array}{c}0.089 \\
(0.067)\end{array}$ & $\begin{array}{l}0.086 \\
(0.067)\end{array}$ & $\begin{array}{l}0.077 \\
(0.101)\end{array}$ \\
\hline Product-Differentiation & & & & $\begin{array}{l}0.272^{* *} \\
(0.112)\end{array}$ \\
\hline Industry-size1 & $\begin{array}{l}-0.121 \\
(0.146)\end{array}$ & $\begin{array}{l}-0.130 \\
(0.146)\end{array}$ & & \\
\hline Industry-size2 & & & $\begin{array}{c}0.306^{* * *} \\
(0.075)\end{array}$ & $\begin{array}{l}0.198^{*} \\
(0.110)\end{array}$ \\
\hline Export & $\begin{array}{l}0.139^{* *} \\
(0.060)\end{array}$ & $\begin{array}{l}0.138^{* *} \\
(0.060)\end{array}$ & $\begin{array}{l}0.138^{* *} \\
(0.060)\end{array}$ & $\begin{array}{l}-0.004 \\
(0.112)\end{array}$ \\
\hline Firm age & $\begin{array}{c}0.006 \\
(0.035)\end{array}$ & $\begin{array}{c}0.005 \\
(0.035)\end{array}$ & $\begin{array}{l}0.004 \\
(0.035)\end{array}$ & $\begin{array}{c}0.060 \\
(0.060)\end{array}$ \\
\hline Market-changes & $\begin{array}{l}0.089^{* *} \\
(0.035)\end{array}$ & $\begin{array}{l}0.090^{* *} \\
(0.035)\end{array}$ & $\begin{array}{l}0.090^{* *} \\
(0.035)\end{array}$ & $\begin{array}{l}-0.021 \\
(0.067)\end{array}$ \\
\hline Product innovation & $\begin{array}{l}0.114^{* * *} \\
(0.042)\end{array}$ & $\begin{array}{l}0.113^{* * *} \\
(0.042)\end{array}$ & $\begin{array}{c}0.113^{* * *} \\
(0.042)\end{array}$ & $\begin{array}{l}0.149^{*} \\
(0.078)\end{array}$ \\
\hline Process innovation & $\begin{array}{l}0.062^{*} \\
(0.037)\end{array}$ & $\begin{array}{l}0.062^{*} \\
(0.037)\end{array}$ & $\begin{array}{l}0.061^{*} \\
(0.037)\end{array}$ & $\begin{array}{c}0.086 \\
(0.068)\end{array}$ \\
\hline$R \& D$ & $\begin{array}{l}0.133^{* * *} \\
(0.052)\end{array}$ & $\begin{array}{l}0.133^{* *} \\
(0.052)\end{array}$ & $\begin{array}{c}0.133^{* * *} \\
(0.052)\end{array}$ & $\begin{array}{l}0.147 \\
(0.094)\end{array}$ \\
\hline Market-competition & $\begin{array}{l}-0.026 \\
(0.050)\end{array}$ & $\begin{array}{l}-0.026 \\
(0.050)\end{array}$ & $\begin{array}{l}-0.026 \\
(0.050)\end{array}$ & $\begin{array}{c}0.078 \\
(0.092)\end{array}$ \\
\hline Foreign-own. & $\begin{array}{c}0.114 \\
(0.089) \\
\end{array}$ & $\begin{array}{r}0.114 \\
(0.089) \\
\end{array}$ & $\begin{array}{c}0.114 \\
(0.089) \\
\end{array}$ & $\begin{array}{r}0.019 \\
(0.163) \\
\end{array}$ \\
\hline Observations & 16993 & 16993 & 16993 & 4848 \\
\hline Number of groups & 2553 & 2553 & 2553 & 2428 \\
\hline Log likelihood & -6912.07 & -6910.91 & -6911.31 & -2091.82 \\
\hline LR test $($ rho $=0)$ & 267.7 & 268.67 & 268.27 & 29.11 \\
\hline Prob>chi2 & 0.000 & 0.000 & 0.000 & 0.000 \\
\hline
\end{tabular}

Notes: All regressions include intercept, unreported sectoral dummies and annual time dummies.

${ }^{a}$ All variables, except the dummies, are in logs

${ }^{\mathrm{b}}$ Numbers in parenthesis are SE.

$*, * *, * * *$ denotes test statistic significance at the $10 \%, 5 \%$ and $1 \%$ level, respectively. 